\begin{tabular}{ll}
\hline 臨 & 床 \\
\hline
\end{tabular}

\title{
重度ブローカ失語症例
}

一 臨床生理学的, 音声学的検査所見について —

小島 好雅・加我 君孝

\section{Neurophysiological and Phoniatrical Studies of a Patient with Severe Broca's Aphasia}

\author{
Yoshimasa Kojima and Kimitaka Kaga \\ (Teikyo University School of Medicine)
}

In a 63-year-old man with severe Broca's aphasia, pure tone audiometry and a series of auditory evoked responses demonstrated preservation of primary auditory pathways. Because he did not speak, the standard language test of aphasia was performed for Broca's aphasia. Since it was impossible to continue further tests, we introduced objective methods to evaluate his aphasic disorder. Phonolaryngograms showed that he was unable even to utter vowel sounds. An electronystagmographic study of eye tracking and OKN revealed abnormal eye movements consistent with a functional disorder in the left cerebral hemisphere. Eye movements during reading clearly showed depression of saccadic gaze phases. Although neurophysiological assessment with writing was not done, it was clear that writing was no better than painting.

Key words: motor aphasia, standard language test of aphasia (SLTA), electronystagmography (ENG), eye movement in reading

はじめに

重度失語症患者の病態は心理学的検査で細办 く評価することが難しく，原因が脳血管障害に よる場合は機能障害も多岐に及んでいることが 多い。言語表出がまったくできない症例では感 覚, 視覚, 運動面に及ぶ複雑な症状の把握は大 変困難であるそそこで，こうした重度失語症患 者に対しては, 心理学的検査を補い神経生理学 的に多角的アプローチを行うことで，障害の程
度との相互関係を明らかにできる可能性がある。 今回我々は，左下前頭回を含み，広範囲に梗塞 巣をもつ重度ブローカ失語の一例を経験し，臨 床生理学的抢よび音声学的手法を用いて標準失 語症検査の各項目に対応した多角的アプローチ を試みたので報告する。

\section{症例}

63 歳, 男性. 主訴は発語困難, 右片麻痺. 既 往歴に高血圧症, 脂肪肝, 高脂血症, 高尿酸血 
症がある。

\section{1. 現病歴}

昭和 62 年 10 月 26 日, 発語困難, 右手のしびれ 感が出現. 発語困難は10分間程で回復したが右 手のしびれ感は残っていた。28日夜，家人は右 足をひきずるように歩くことに気付いていたが 本人は気にせず放置していた，29日朝，ベット から落ちているのを家人が発見, 呼びかけに応 答がなく意識不清明，失禁していたため救急車 で当院救急外来受診，即日入院となった.

2 . 検查所見

1 ) 神経学的所見

右不全麻痺を認め, 右膝部は硬直し伸展困難 であった、不随意運動は認めなかった。深部反 射では, 上腕二頭筋反射, 上腕三頭筋反射, 腕 橈骨筋反射は消失して括り, 膝蓋腱反射, アキ レス腱反射は六進していた。病的反射は Babinski 反射と Chaddock 反射が陽性であった。脳 神経症状は舌咽神経 $(\mathbb{X})$ 麻㽻を除さ異常を認め なかった。

\section{2 ) CT 所見}

左下前頭回を含久, 中心前回, 一部頭頂, 側 頭葉に及ぶ境界鮮明な梗塞巣を認めた（図 1 ).

3 ) 心理学的検查所見

純音聴力検査では高音漸傾型の難聴がみられ たが，語音聴取域の聴力は比較的良く保たれて いた. 3 点平均聴力は右 $30 \mathrm{~dB}$, 左 $32 \mathrm{~dB}$ であ った。

発症後 4 力月から 8 力月の間に標準失語症検 查 (standard language test of aphasia : SLTA) を計 3 回行った(図 2 )。「聴く」では, “口頭命 令に従ら”は経過を通じまったくできなかった が，“単語の理解” “短文の理解” の能力はある 程度残っており，またこれらは徐々に回復する 傾向にあった。「話す」では, “呼称”〜“短文の 音読”のすべての項目に扣いてまったく解答が 不可能であり，さらに現在に至るまで有意語の 発音はできない状態である。「読む」は“書字 命令に従う”以外は比較的良く保たれており, 経過中回復傾向を示した。“漢字・単語の理解” は “仮名・単語の理解”より常に成績が良かっ

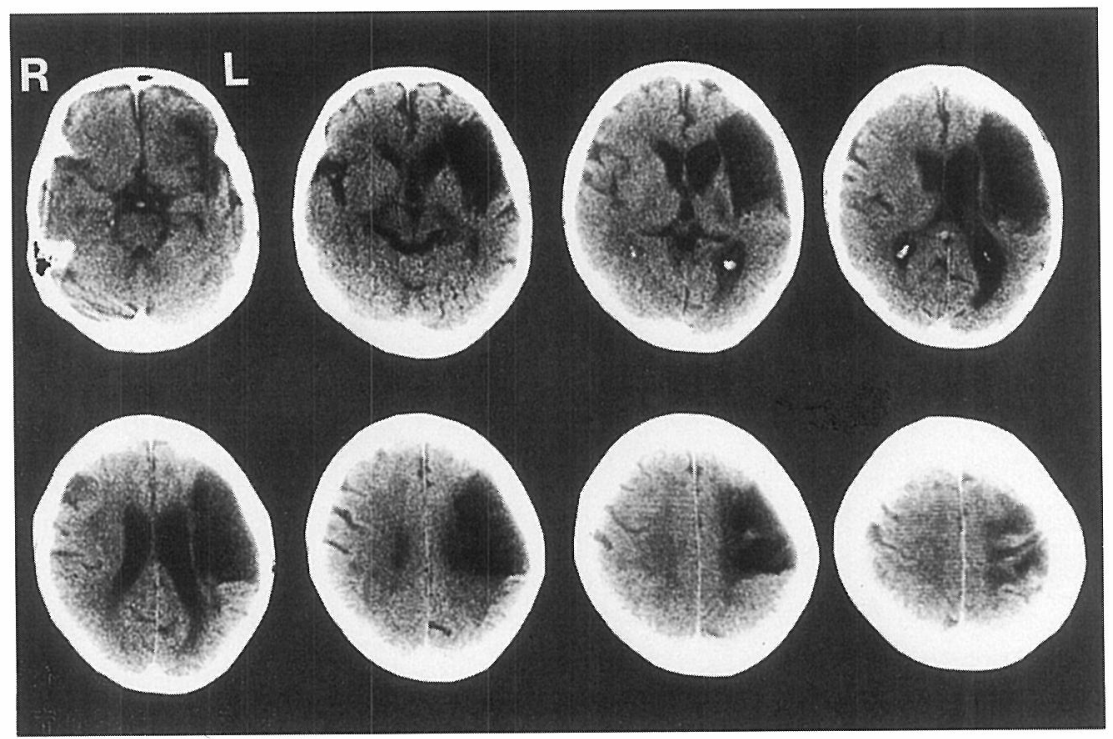

図 1 brain CT (発症後 8 力月)

梗塞巣を中心に 8 枚の連続したスライスを示す. 
た。図 3 に示すように「書く」では「話す」と

同様に有意語の書字は汪とんど不可能であった。

「計算」も汪とんどできなかった。

4) 描画テスト

代表的な描画を図 3 に示した。描画は稚拙な がら形が整っていた。

\section{方法}

標準失語症検査の大項目のうち「聴く」，「話 す」「読む」に対応した神経生理学的アプロー チとして次のような検査を施行した.

\section{1.「聴 $<」$ 項目}

聴覚面の障害を聴性脳幹反応 (auditory brainstem response : ABR), 聴性中間反応 (auditory middle letency response : MLR), 頭頂部緩反 応 (slow vertex response：SVR)により調べた。

2.「話す」項目

自発筋電困により前頭筋，眼輪筋，口輪筋の 麻痺の程度を検査した。音声障害の有無をソナ グラムを用いて調べた。

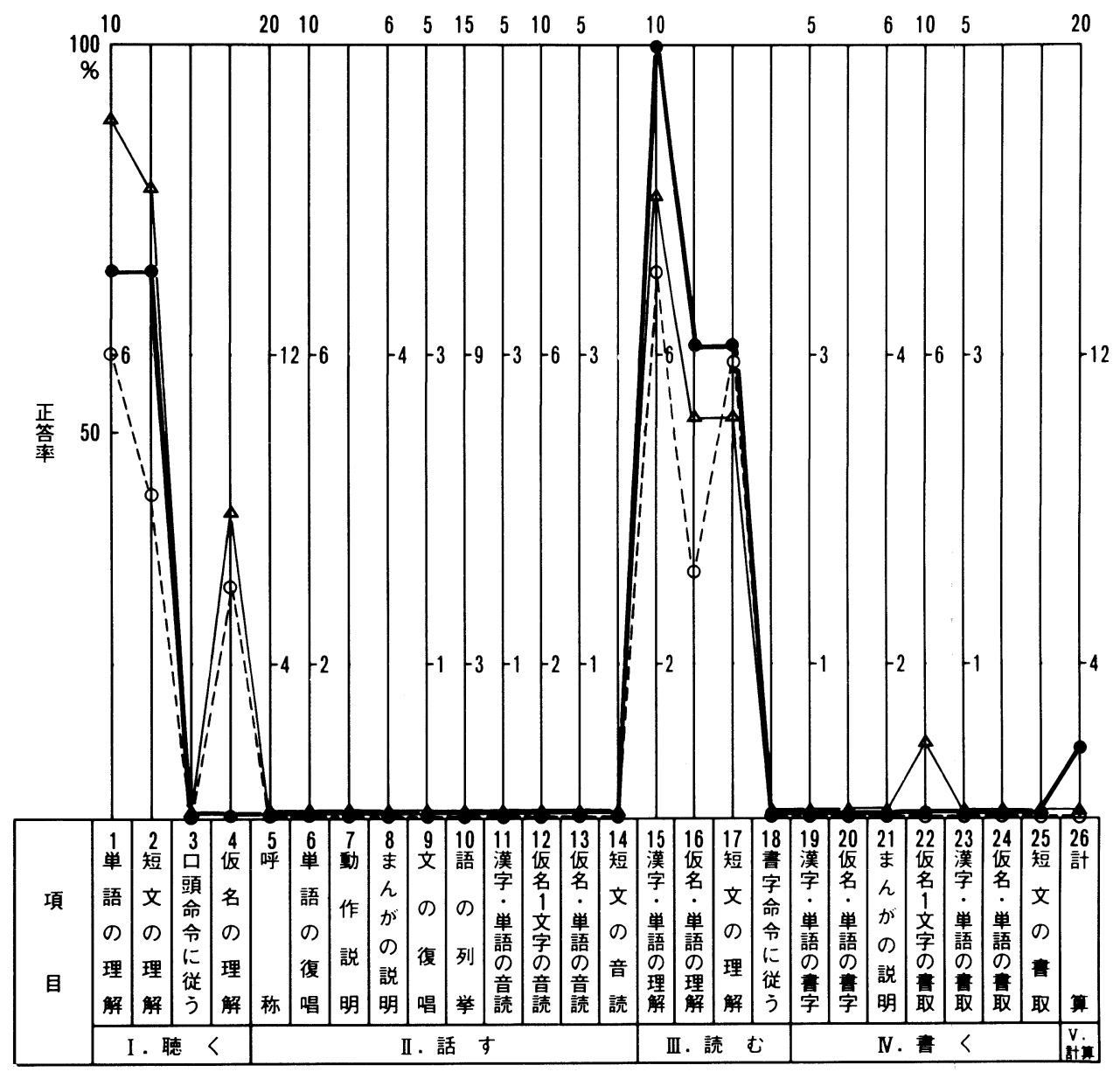

図 2 標準失語症検査成績

S63. 2.17

S63. 4.28

S63. 6.28 


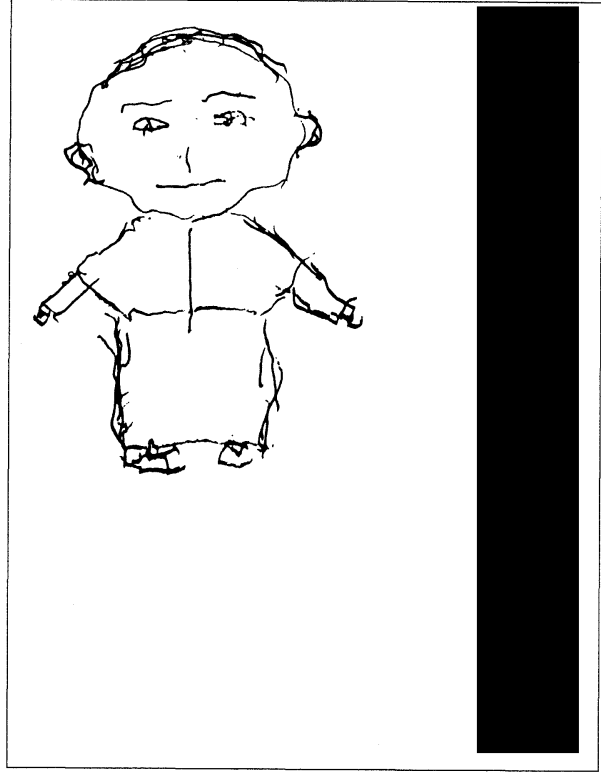

図 3 書字と描画 (発症後 8 力月)

書字の課題は自分の名前である. 描画は人の 絵を書いてもらった。
3.「読む」項目

ENG (electronystagmography)により注視, 滑動性眼球運動, 衝動性眼球運動の障害と読字 の際の眼球運動の障害とを比較した。これらは 「話す」項目のなかの “短文の音読”とも関係 の深い検査である。

\section{結果}

1.「聴 $<」$ 項目

聴性誘発反応の結果を図 4 亿示す. ABR は $80 \mathrm{~dB}$ のクリック音の 1000 回加算で記録した. 波形は正常であった。 I 波, V 波の潜時に軽度 延長がみられたが V-I 波間隔は正常であった. MLR は $80 \mathrm{~dB}$ のリック音, 200回加算で行 った．波形は $\mathrm{N}_{\mathrm{a}}, \mathrm{P}_{\mathrm{a}}, \mathrm{P}_{\mathrm{b}}$ 成分が左右差なく正 常波形を示した. SVRは $80 \mathrm{~dB}$ のクッック音, 50 回加算で行った。波形は $\mathrm{P}_{1}, \mathrm{~N}_{1}, \mathrm{P}_{2}$ 成分を 左右とも認めた.

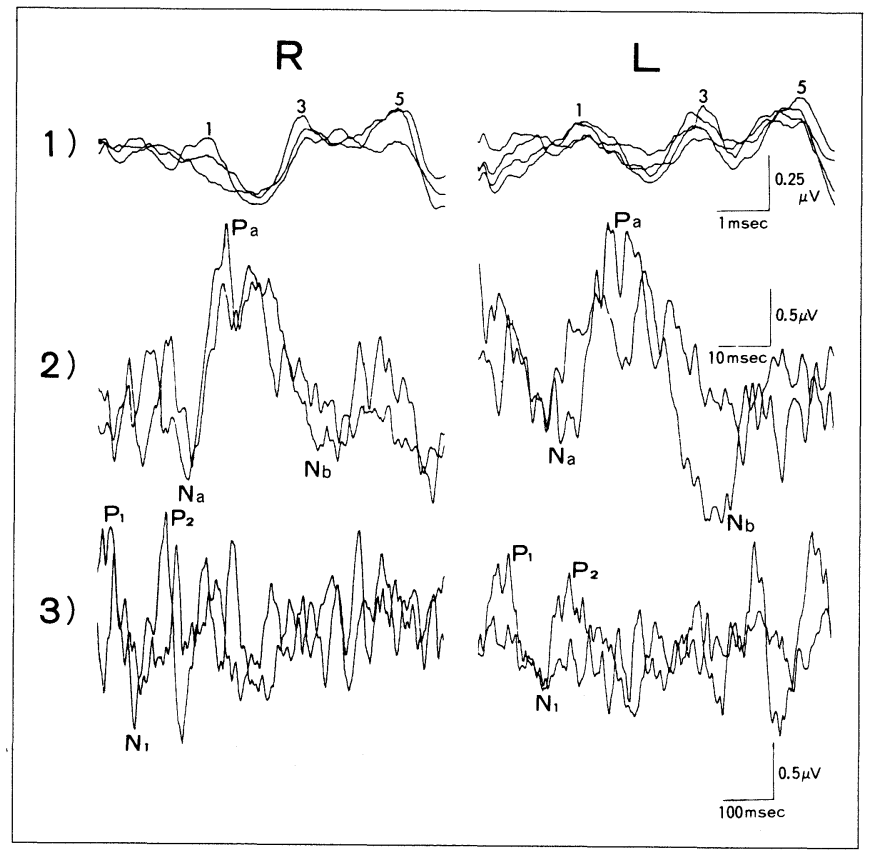

図 4 聴性誘発反応 (発症後 8 力月)
1) 聴性脳幹反応 (ABR)
2) 聴性中間反応 (MLR)
3 ）頭頂部緩反応 (SVR) 
2.「話す」項目

1 ）顔面神経領域の筋電困

自発筋電図の結果では前頭筋に左右差を認め ず，眼輪筋の左右差は顕著ではなかった。一方， 口輪笳は左側 (健側) に対し, 右側 (患側)の反応 が弱く，右不全麻痺を認めた。

2 ) 音声の音響分析

症例は自分の名前, 住所などの発語をらなが すと母音に近い未分化な声を発声できるが，こ れ以外の母音の発声は不可能であり，子音の発 音もまったくできなかった。図 5 にこの未分化 な声をりナグラムにより音響分析した結果を示 す. 第 1 フォルマントが認められるが，第 2 , 3 フォルマントは明らかでなく，6〜7 kHzの ノイズの混入が著明である。これは日本語の音 節として聴取しにくい音であった。

3.「読む」項目

1) ENG による眼球運動検査

(1)二点交互視検査 (左右 $10^{\circ}$ 視検査)

二点交互視検査では右方，左方の眼球運動之 もにサッケード運動に軽度の undershootを認 めた(図 6-1).

(2)視標追跡運動検查 (eye tracking test： ETT)

右から左方向運動時の追従運動は階段状波形 を示して円滑さを欠き, 滑動性眼球運動にマイ クロサッケードが混在している。これに対し右
方向運動時の追従運動は比較的滑らかであった (図 6-2).

(3)視運動性眼振検査 (optkinetic pattern test : OKP)

右側 (健側) 一急速相をもつ視運動性眼振 $(\mathrm{OKN})$ の解発は不良であり, 視標の速度上昇 時に眼球急速相, 緩徐相ともに運動速度は低下 した(図 6-3)。左側(患側)へ急速相をもつ $\mathrm{OKN}$ の解発は比較的良好であった。すなわち 左への眼振方向優位性を認めた.

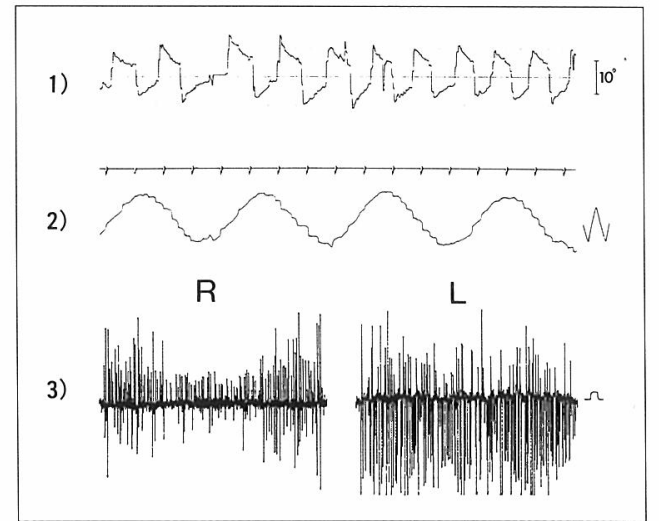

図 6 ENG (発症後 5 力月)

1) 二点交互視検査

2 ) 視標追跡運動検查 (ETT)

3 ) 視運動性眼振検查 (OKP)

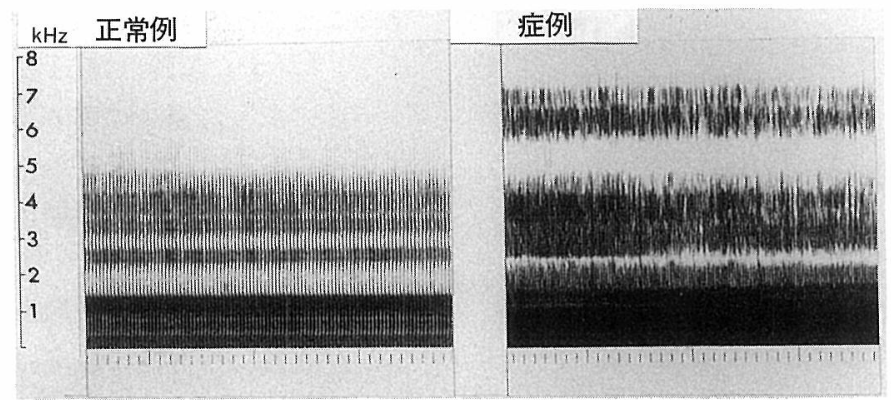

図 5 ソナグラムによる「ア」の発音

正常例は基本となる $0.7 \sim 0.8 \mathrm{kHz}$ 附近の $\mathrm{F}_{1}$ と $1.1 \sim 1.2 \mathrm{kHz}$ 附近 の $\mathrm{F}_{2}$ とがはっきりしている. 症例は $0 \sim 1.4 \mathrm{kHz}$ のスペクトルが 一様に強くフォルマントが分離できない。 


\section{(4)読字の眼球運動検査}

図 7 亿示すよらに，正常者では単語あるいは 文節を一つの単位として文字を読んで拈り，次 の文節に移るとさにサッケードが执こり全体と して階段状波形を形成し，これが改行するごと に繰り返されている112)。階段の数は被験者が とらえた文節(かたまり)の数と同じである。左 方向への大きなサッケード運動は改行を表して いる.

本症例では改行ごとの左方向へのサッケード 運動は認められ，課題を理解し文章を読もらと していることはわかるが，階段状波形が形成さ れて打らず階段の数を数えることはできない。 注視部分にもいたるところに停止，後戻りが認 められている。

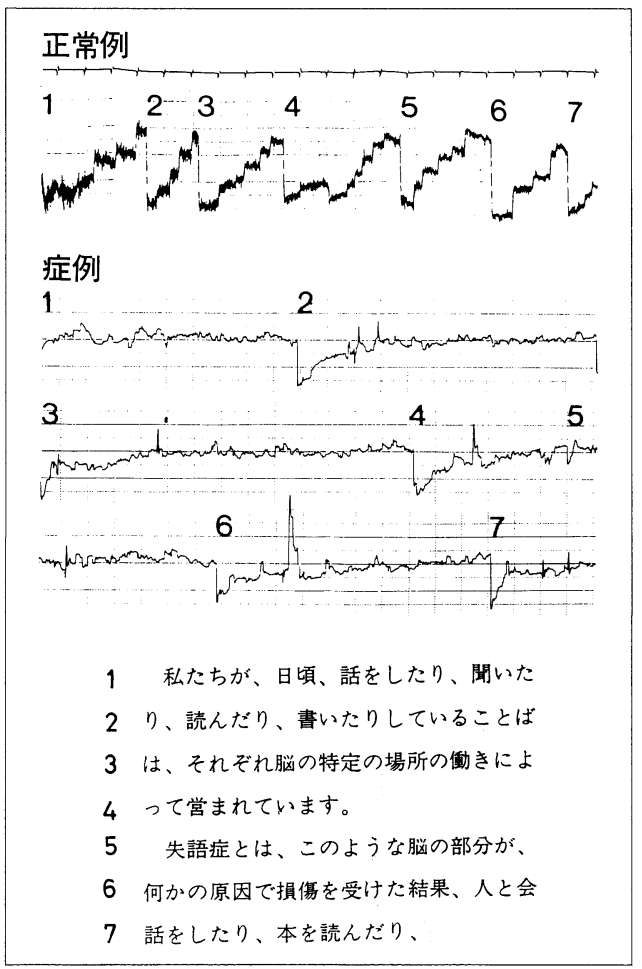

図 7 読字の眼球運動検查 (発症後 7 力月) 正常例, 症例とも図の数字は行を表し, 下の文章の数字に対応する.

\section{考察}

重度のブローカ失語のため心理学的検査では, 読む項目は軽度の障害を示し, 聴く項目では中 等度〜高度の障害を示し，話す，書く項目はま ったく解答不可能であった。この結果を生理学 的, 音声学的検査結果と比較検討する.

1.「聴く」課題に打ける標準失語症検査 (SLTA)の結果は，簡単なものは良く保たれて おり，また徐々に回復してきた，反面，“口頭 命令に従ら”“仮名の理解”のような難易度の 高い課題については成績が悪く，大きな変化は 期待できない状態であった。

ABR では潜時に軽度の延長がみられ，これ は純音聴力検査で示された軽度の感音性難聴3) によるものであるが脳幹障害は認めない。

MLR では潜時に延長がみられたが，波形は 右側は Ozdamar と Krausによる分類4)の I 型 あるいは开型，左側は而型に属すると考兄られ， いずれにしても正常範囲内とみることができた.

SVRの結果も正常範用とみることができた. これらの検査結果は, 中枢性の聴覚伝導路障害 が生理学的に認められないことを示唆している。 すなわち本症例では聴覚の求心路は保存されて いると推察され, さらにSLTAの結果では “単 語の理解”, “短文の理解” は比較的上く保たれ ていることから, “口頭命令に従う”ことがで きないのは, “口頭命令” の理解は可能でも“従 ら”といら運動行為に発展しないことが問題で あることを示唆している。

2.「話す」課題はSLTA でまったく解答が 不可能であり，意味のある言語表出はまったく なされなかった。自発筋電図の結果明らかにさ れた顔面神経麻痺は前頭筋に左右差なく口輪筇 に顕著であり，CT 所見で梗塞は中心前回を含 むことから中枢性の不全麻痺であると考えられ るが，麻痺は一側性で程度は軽く，少なくとも 口唇音の構音に支障をきたす麻痺はない。しか し, ソナグラムでは声帯運動やほかの構音器官 の障害を認めないにもかかわらず母音すら形成 されていなかった。これは，「話す」の障害は 
単に口輪筋や構音にあずかる諸筋の不全麻痺に よるだけではなく, 単音や有意語の発語運動の 前段階である発語に関する運動行為の形成に障 害があり, 失行のように構音時の総合的な協調 運動ができないことを示唆している.

3.「読む」課題はSLTA の各評価項目の中 でもっとも成績がよかった. “漢字・単語の理 解” は最終的には $100 \%$ の正答率となった。こ れに対し “短文の理解”, “書字命令に従う”な どは成績が悪く，また経過を通じ変化がなかっ た. 本症例の眼球運動検查, および読字の眼球 運動検査の結果について考察する.

二点交互視すなわち水平方向に随意性に眼が 急速に動く運動(衝動性眼球運動) そおいて本症 例にみられた hypometria は両側性であり極め て軽度にすぎず，読字を困難にするものではな いと思われた。

視標追跡検査に打いて右から左方向運動時に 認められた saccadic pursuit は大脳疾患では左 側の障害を示唆している5 。追跡性眼球運動の 神経機構は注視の神経機構とほぼ同様であり, 注視の中枢としては前頭眼野, 頭頂葉, 小脳な ぞが考えられている6). したがって本症例では 左大脳半球前頭葉から頭頂葉レベルの梗塞によ る障害が saccadic pursuit の原因と考えられる.

視運動性眼振検查に扣いて認めた左への眼振 方向優位性は左大脳半球の広範な障害があるこ とを示唆して扣り7), 本症例では左側前頭葉か ら頭頂, 側頭葉の広範な梗塞が原因と考学られ る.

読字の眼球運動検査では右方向へのサッケー ド運動が認められず，注視相も完全な固視では なく後戻りが頻発していた。本検査では言語理 解, 言語表出扣よび滑動性眼球運動, 衝動性眼 球運動のいずれに障害があっても波形が異常と なる。とくに大脳の広範な梗塞では言語面, 眼 球運動面の両者に障害がある場合が多く, 検査 結果の異常がどの部位の障害に由来するのかの 判断は, 活かの言語面, 眼球運動の検査結果之 併せて慎重に行ら必要がある。本症例では衝動
性眼球運動はほぼ保たれておりり, 滑動性眼球運 動では右から左方向運動時にのみ異常を認めた が，左から右方向の眼球運動はよく保たれてい た.これらの結果から眼球運動系の障害は, 少 なくとも左から右へ横書きで書かれた文を読む 際に与える影響はあまりないものと思われる。 一方, 読字の眼球運動検査では, 正常な注視と サッケード運動はまったく認められなかった。 すなわち, 本症例は眼球運動系の機能は注添保 たれているものの，言語面に大きな障害があり， これが読字の眼球運動検査での異常の原因と考 えられる。

以上のように，心理学的検査と神経生理学的 検査の結果を総合的に分析することにより,「聴 く」項目の機能障害に聴覚系の関与は汪とんど ないこと,「話す」項目の機能障害は標準失語 症検査でまったく解答が不可能であり, 障害の 程度を判定することが困難であったが，ソナグ ラムの結果より発声はできるが構音はまったく できず発語以前の問題があることを明らかにす ることができた、「読む」項目では読字の眼球 運動検査で文字を読む際の右方向への有効なサ ッケード運動が汪とんどなく，正常な階段状波 形はまったく形成されていなかったが，二点交 互視検查, 視標追跡運動検査では読字を困難に する活どの眼球運動障害はないと思われ, 標準 失語症検査の結果により言語表出面の障害によ ることが推察できた.

今回行ったように, 標準失語症検査 (SLTA) をはじめとする心理学的検查でまったく解答が できない場合でも, 臨床生理学, 音声学的検査 と組み合わせることにより，障害の程度と残さ れた機能がある程度明確にできる場合もあるこ とがわかった。

\section{まとめ}

左下前頭回を含む左半球の広範囲に梗塞巣を もつ重度ブロ一カ失語の一例に対し, 標準失語 症検査 (SLTA)の大項目に対応した臨床生理学, 音声学的検査を施行した.

1.「聴く」項目では, ABR, MLR, SVR は 
正常範囲であった．聴覚認知は中等度障害され ていた.

2.「話す」項目では，ソナグラムで分析し たところ単音の構音すらできないことがわかっ た。

3.「読む」項目では，ENGで調べたとこ ろ眼球運動系には異常を認めないが，読字，眼 球運動障害は高度であった。

4. 以上より本例の聴覚的理解と音声, 言語 表出, 扣よび文の理解と音読の障害はブローカ 失語を主とするらち言語障害そのものの影響で あることを示している。

稿を終えるにあたり, 研究に際しご指導, ご協力 をいただいた当科進藤美津子講師, 橋本佳子の両氏 に心から感謝いたします。

\section{引用文献}

1) Pavlidis G Th : The "Dysleia Syndrome" and its objective diagnosis by erratic eye movements. Eye Movement in Reading (ed by Keith Rayner). pp 441 463, Academic Press, London, 1983.

2) Olson RK , Kliegl R and Davidson BJ : Eye movement in reading disability. Eye Movement in Reading. pp 467 479, Academic Press, London, 1983.

3）設楽哲也: 耳鼻咽喉科領域に括ける年路变化. 65 93頁，世紀社出版，東京， 1980 .

4) Ozdermar $\mathrm{O}$ and Kraus $\mathrm{N}$ : Auditory middlelatency responses in human. Audiology 22 : 34 49, 1983.

5）小松崎篤, 篠田義一, 丸尾敏夫 : 眼球運動の神 経学. 235頁, 医学書院, 東京, 1985.

6）時田 喬, 鈴木淳一, 曽田豊二 : 神経耳科学 I 81頁，金原出版，東京， 1985 .

7）小松崎篤, 篠田義一, 丸尾敏夫 : 眼球運動の神 経学. 305頁, 医学書院, 東京, 1985.

$$
\left.\begin{array}{l}
\text { 原稿受付 : 平成 } 3 \text { 年 } 9 \text { 月 } 19 \text { 日 } \\
\text { 原稿採択 : 平成 } 3 \text { 年11月 } 25 \text { 日 } \\
\text { 別刷請求先 : 小島好雅 } \\
\text { T1 } 173 \text { 東京都板橋区加賀 2-11-1 } \\
\text { 帝京大学医学部耳鼻咽喉科学教室 }
\end{array}\right)
$$

